\title{
Representação fonológica em crianças com Distúrbio Específico de Linguagem (DEL)****
}

\author{
Phonological representation of children with Specific Language \\ Impairment (SLI)
}

\author{
Debora Maria Befi-Lopes* \\ Ana Carulina Spinardi Pereira** \\ Ana Carolina Paiva Bento***
}

*Fonoaudióloga. Livre-Docente do Curso de Fonoaudiologia da Faculdade de Medicina da Universidade de São Paulo (FMUSP). Professora Associada do Departamento de Fisioterapia, Fonoaudiologia e Terapia Ocupacional da FMUSP. Endereço para correspondência: Rua Cipotânea, 51 São Paulo - SP - CEP 05360-160 (dmblopes@usp.br).

**Fonoaudióloga. Mestre em Fonoaudiologia pela Faculdade de Odontologia de Bauru da USP. Docente do Curso de Fonoaudiologia da Fundação Educacional de Fernandópolis.

***Fonoaudióloga. Doutoranda em Ciências da Reabilitação na Área de Comunicação Humana pela FMUSP. Departamento de Fisioterapia, Fonoaudiologia e Terapia Ocupacional da FMUSP.

****Trabalho Realizado no Laboratório de Investigação Fonoaudiológica em Alterações do Desenvolvimento da Linguagem do Curso de Fonoaudiologia do Departamento de Fisioterapia, Fonoaudiologia e Terapia Ocupacional da FMUSP.

Artigo Original de Pesquisa

Artigo Submetido a Avaliação por Pares

Conflito de Interesse: não

Recebido em 15.05.2009.

Revisado em 01.12.2009; 10.03.2010; 09.06.2010.

Aceito para Publicação em 27.08.2010.

\section{Abstract}

Background: children with Specific Language Impairment (SLI) have difficulties with speech processing. These difficulties affect the development of phonologic representations. Aim: to evaluate the abilities of children with normal language development (NLD) and those with SLI in distinguishing words from nonwords in a lexical decision task. Method: two groups were involved in this study: the Control Group (GC), with no language disorders, composed by 36 subjects, and the Research Group (RG), with 18 subjects, all diagnosed with SLI, aging form 4 to 8:9 years. Children from both groups were arranged in three subgroups, according to the receptive vocabulary. Forty eight three syllable words were selected, being 24 real words and 24 that were manipulated in order to obtain non-words. Three variables were considered: (a) modification extension, (b) modification positioning and (c) modification type. Children had to decide whether a phonological sequence consisted of a word or a non-word. Results: even though children were matched by lexical age, there were differences between GC and RG. The RG presented more difficulty in lexical decision, not only for words but also for non-words. Both groups, with lexical age of 4 years, struggled more in this task when compared with groups with lexical age of 5 and 6 years. Conclusion: children with SLI presented deficit in phonological representation when compared with children with NLD. This difference in performance can be explained by differences in the formation and retention of working memory representations, auditory discrimination and motor planning and execution.

Key Words: Language Development; Language Development Disorders; Child.

\section{Resumo}

Tema: crianças com Distúrbio Especifico de Linguagem (DEL) apresentam dificuldades no processamento de fala e esses prejuízos afetam o desenvolvimento de representações fonológicas. Objetivo: avaliar as habilidades de crianças em Desenvolvimento Normal de Linguagem (DNL) e com DEL em distinguir palavras de pseudopalavras em uma tarefa de decisão lexical. Método: participaram deste estudo dois grupos: Grupo Controle (GC), sem alterações de linguagem, composto por 36 sujeitos, e Grupo Pesquisa (GP), 18 sujeitos, com diagnóstico de DEL, com idades entre 4:0 - 8;9 anos. As crianças de ambos os grupos foram distribuídas em 3 subgrupos de acordo com o vocabulário receptivo. Foram selecionadas 48 palavras trissílabas, sendo 24 palavras reais e 24 que foram manipuladas a fim de se obter pseudopalavras. Três variáveis foram consideradas: (a) extensão de modificação, (b) posição de modificação e (c) tipo de modificação. As crianças deveriam decidir se uma sequência fonológica falada consistia de uma palavra ou não. Resultados: mesmo sendo pareados por idade lexical houve diferença entre os GP e o GC, sendo que o GP apresentou maior dificuldade na decisão lexical tanto de palavras quanto de pseudopalavras. Ambos os grupos com idade lexical de 4 anos apresentaram maior dificuldade na tarefa se compararmos aos grupos de idade lexical maior (5 e 6 anos). Conclusões: crianças com DEL apresentam déficit na representação fonológica quando comparadas com crianças em DNL e esta diferença de desempenho pode ser explicada pela diferença na formação e retenção das representações na memória de trabalho, discriminação auditiva e planejamento e execução motora.

Palavras-Chave: Desenvolvimento da Linguagem; Transtornos do Desenvolvimento da Linguagem; Criança.

Referenciar este material como:

Befi-Lopes DM, Pereira ACS, Bento ACP. Phonological representation of children with Specific Language Impairment (SLI) (original title: Representação fonológica $\sum 3$ em crianças com Distúrbio Específico de Linguagem (DEL)). Pró-Fono Revista de Atualização Científica. 2010 jul-set;22(3):305-10. 


\section{Introduction}

The term phonological representation is used to describe the storage of phonological information about words in long term memory.1

The building process of these representations is still not completely understood, especially for children with Specific Language Impairment (SLI). 2

Although different factors may explain the difficulties with phonological representations observed in children with SLI, authors have suggested that these deficits might be related to the quality of these representations. The representations of children with SLI would be more holistic, similarly to representations of younger children with typical language development.3

Phonological abilities can be investigated through nonword repetition tasks4. In addition, studies have used other types of tasks to investigate the phonological representations in children, such as naming5,6,7, gating paradigm 8,9 and lexical decision task. 2,10

Considering the abovementioned literature facts, this study was based on the study Phonological Representations in Children with SLI: A study of French 2. The purpose of the study was to analyze the abilities of typically developing children and children with SLI to distinguish words from nonwords in a lexical decision task. This type of task induces an excessive demand on phonological processing. 10

\section{Method}

This study was approved by the Research Committee of the Department of Physical Therapy, Speech and Hearing Sciences and Occupational Therapy of the Medical School of University of São Paulo (Faculdade de Medicina da Universidade de São Paulo - FMUSP) under number 047/05. All participants signed a consent form.

\section{Participants}

The study included 54 children who composed two groups: the study group and the control group.

The Study Group (SG) consisted of 18 children with SLI, aged between 3;8 and 8;9 years. Thirteen children (72.2\%) were boys and five (27.8\%) were girls. All children were, at the moment of data collection, receiving Speech-Language therapy at the Laboratory for Investigation in Language Development and Alterations (LIF-ADL) of FMUSP.
The control group (CG) consisted of 36 children with typical language development aged between 4;1 and 6;8 years. Twenty children (55.6\%) were boys and 16 (44.4\%) were girls. All children from the CG were, at the moment of data collection, enrolled at day-care centers and EMEIs located in the southern of the city of Sao Paulo. The inclusion criteria for this group were: no language complaints and disorders according to reports from teachers and according to information provided by parents or guardians; and performance within or above the expected for age in the test of receptive vocabulary used at the LIF-ADL 11.

In both groups, children were divided into three subgroups according to the performance obtained in the test of receptive vocabulary. Thus, subgroups were set at four, five and six years according to the "lexical age" of each child. Chronological age was not considered in any of the groups.

The CG was divided into: Control Subgroup I (CSBI) - lexical age of four years, according to reference values for the abovementioned test. The CSBI was composed of 10 children from 4;1 to 4;11 years; Control Subgroup II (CSBII) - lexical age of five years. The CSBII was composed for 12 children from 5;1 to 5;7 years; and Control Subgroup III (CSBIII) - lexical age of six years. The CSBIII was composed of 14 children from 6;0 to 6;8.

The SG was divided into: Study Subgroup I (SSBI) - lexical age of 4 years. The SSBI was composed of five children from 3;8 to 5;0 years; Study Subgroup II (SSBII) - lexical age of five years. The SSBII was composed of six children from 4;10 to 7;9 years; and Study Subgroup III (SSBIII) lexical age of six years. The SSBIII was composed of seven children from 4;10 to 8;9 years.

\section{Material}

We selected 48 three-syllable words from the expressive vocabulary test of the ABFW Child Language Test (Teste de Linguagem Infantil ABFW). 12 We opted to use words from such test considering that they are familiar words to children and that there are no studies reporting the frequency of words in Brazilian-Portuguese in oral language. High-frequency French words selected from a French database were used on the baseline study for the present research2.

The words were divided into two groups. The first group was composed of 24 real words, i.e. without modification. The second group was composed of 24 nonwords created through manipulation of real words. 
Three variables were analyzed: (a) modification extent, (b) modification position, and (c) modification type.

The first variable corresponds to maintenances (classified as a mild modification) or not (classified as important modification) in the number of syllables of the original word, i.e. the one that originated the nonword. For example: tônibus derived from ônibus (bus) and ticidade derived from the cidade (city). Regarding the position of modification, the words were manipulated in three positions - initial, medial and final. The third variable corresponded to deletion or addition of elements (syllables or phonemes) to the original word. Some examples of stimuli used are detailed in Table 1.

Procedures

We used a lexical decision task in which children had to decide whether a phonetic sequence consisted of a real word or not. Participants were informed they would hear some words and were instructed to respond "yes" when they heard a real word and "no" when they heard a word that did not exist.

A practice session consisting of four items was carried out to assure comprehension of procedures. The stimuli were randomly presented and the same order was used for all children.

TABLE 1. Examples of stimuli used on the lexical decision task.

\begin{tabular}{ccccc}
\hline $\begin{array}{c}\text { Original } \\
\text { Word }\end{array}$ & Pseudoword & \multicolumn{3}{c}{ Processes used } \\
\hline & & a & b & c \\
Abajur & Ablajur & Mild & Medial & Adding \\
Quadrado & Adrado & Mild & Initial & Deletion \\
Xícara & Xibícara & Important & Medial & Adding \\
Igreja & Igre & Important & Final & Deletion \\
\hline
\end{tabular}

\section{Results}

The following parametric tests were used for statistical analysis: t test for independent samples, t test for paired samples - considering equality of variances - and analysis of variance (ANOVA). The significance level adopted was of 5\%.

Table 2 displays the performance of all subgroups in each condition.

Children of the lexical age of four CG subgroup performed better in word recognition than children from the same subgroup of $S G(F=7.44, p=0.017)$. Regarding the nonword recognition, no statistically significant between groups difference was observed $(F=0.25, p=0.626)$. For overall performance, a trend toward better performance of the CG when compared to SG was observed $(\mathrm{F}=4.61, \mathrm{p}=0.051$ ) and maybe the significance would be confirmed with sample increase.

For the subgroups of lexical age of five, the CG showed better performance in words ( $\mathrm{F}=34.09$, $\mathrm{p}$ $<0.001$ ), nonwords ( $\mathrm{F}=19.18, \mathrm{p}<0.001)$ and overall accuracy $(\mathrm{F}=26.92, \mathrm{p}<0.001)$ as compared to the SG. For the subgroups of lexical age of six, the CG children also showed better performance in all conditions when compared to the SG: words ( $\mathrm{F}=$ 9.22, $\mathrm{p}=0.006)$, nonwords $(\mathrm{F}=19.05, \mathrm{p}<0.001)$ and overall accuracy ( $\mathrm{F}=21.35, \mathrm{p}<0.001)$.

Considering the age factor, the subgroup of lexical age of four of the CG performed significantly worse than the subgroups of five and six years in words ( $\mathrm{F}=17.39$, $\mathrm{p}<0.001$ ), nonwords ( $\mathrm{F}=68.29$, $\mathrm{p}$ $<0.001)$, and overall accuracy $(\mathrm{F}=81.23, \mathrm{p}<0.001)$. For children from the SG, the subgroup of lexical age of four performed significantly worse than the one of six years in words $(\mathrm{F}=4.49, \mathrm{p}=0.027$ ), nonwords $(\mathrm{F}=7.27, \mathrm{p}=0.005)$ and overall accuracy $(\mathrm{F}=11.63, \mathrm{p}=0.001)$. Thus, children from the subgroup of lexical age of five of CG had similar performance to the subgroup of six year. The performance of children with lexical age of five years from the SG is similar to the one observed on subgroup of lexical age of four.

Regarding the extent of nonwords manipulation, we observed that, at the lexical age of four, the two groups had similar performance when the manipulation was mild $(\mathrm{T}=0.46, \mathrm{p}=0.655)$ or important $(T=1.27, p=0.225)$. At the lexical age of five and six years, the CG children had better performance in both conditions, mild ( $\mathrm{T}=4.38$, $\mathrm{p}$ $<0.001, \mathrm{~T}=4.44, \mathrm{p}<0.001)$ and important $(\mathrm{T}=4.03$, $\mathrm{p}=0.001, \mathrm{~T}=2.83, \mathrm{p}=0.009$ ).

Comparing the mild and important manipulations within-ages, children of the subgroups with lexical age of four of CG had similar performance $(\mathrm{T}=0.51, \mathrm{p}=0.619)$, while children from the SG showed poorer performance on the important manipulation condition $(\mathrm{T}=9,00, \mathrm{p}=$ 0.001). As for children of the subgroups of five and six years, the groups showed no effect of mild and/ or important manipulation: five years (control - $\mathrm{T}=$ 1.00, $\mathrm{p}=0.339$; study $-\mathrm{T}=0.18, \mathrm{p}=0.867$ ) and six years (control $-\mathrm{T}=-1.24, \mathrm{p}=0.231$; study $-\mathrm{T}=0.73$, $\mathrm{p}=0.489)$. 
Regarding addition, children from the subgroup of lexical age of four of the CG showed similar performance to the same lexical age subgroup of SG $(T=-0.11, p=0.910)$, whereas the five and six years CG subgroups had a higher performance ( $\mathrm{T}$ $=4,14, p=0.001, T=3.03, p=0.006$ ). In relation to the deletion, we observed the same pattern, in which the groups did not differ at four years $(\mathrm{T}=$ $0.86, p=0.404$ ) and at five and six years the performance of the CG was significantly better $(\mathrm{T}=$ $3.73 \mathrm{p}=0.002, \mathrm{~T}=2.89, \mathrm{p}=0.008$ ).

When analyzing the manipulation position, we observed that, children of the subgroup of four years presented a trend to a better performance at initial position $(\mathrm{T}=1.79, \mathrm{p}=0.096)$ whereas the subgroup of five years presented a better performance at modifications presented at initial position $(T=3,32, p=0.004)$. Because the performance of all children from the CG was identical, we were unable to perform the analysis for subgroups of six years. When the manipulation occurred in medial syllable, children of the subgroup of four years of the CG showed similar performance to their peers of the $\mathrm{SG}(\mathrm{T}=-0.32, \mathrm{P}=0.757)$; at five years, children from the CG showed better performance $(\mathrm{T}=3.47, \mathrm{p}=0.018)$; at six years, a trend towards better performance of the CG was observed $(\mathrm{T}=2.11, \mathrm{p}=0.064)$. When the manipulation occurred in the final position, there was no statistically significant difference between subgroups of four and six years $(\mathrm{T}=-1.17, \mathrm{p}=$ $0.263, \mathrm{~T}=0.74, \mathrm{p}=0.468$ ). As for the age of five, $\mathrm{a}$ trend toward better performance of CG in relation to SG was observed $(T=0,2,24, p=0.076)$.

\section{Discussion}

We observed a statistically significant difference between the Study and the Control groups in the lexical decision task. The SG performance was below the one observed for the CG. This provides evidence that children with SLI have deficits in phonological representations and such data are in agreement with other recent studies. 13
TABLE 2. Mean and Standard Deviation values for each condition according to lexical age.

\begin{tabular}{|c|c|c|c|c|}
\hline & $\begin{array}{c}\text { LEXICAL } \\
\text { AGE }\end{array}$ & GROUP & $\begin{array}{c}\text { MEAN } \\
\text { ACCURACY }\end{array}$ & $\begin{array}{l}\text { STANDARD } \\
\text { DEVIATION }\end{array}$ \\
\hline \multirow{6}{*}{ Words } & $4: 0$ & Control & 21,00 & 2,00 \\
\hline & & Study & 16,40 & 4,67 \\
\hline & $5: 0$ & Control & 23,83 & 0,58 \\
\hline & & Study & 20,33 & 1,97 \\
\hline & $6: 0$ & Control & 23,50 & 0,99 \\
\hline & & Study & 21,44 & 2,55 \\
\hline \multirow{6}{*}{ Nonwords } & $4: 0$ & Control & 10,80 & 5,63 \\
\hline & & Study & 9,40 & 3,71 \\
\hline & $5: 0$ & Control & 23,50 & 1,24 \\
\hline & & Study & 13,83 & 7,68 \\
\hline & $6: 0$ & Control & 23,33 & 1,09 \\
\hline & & Study & 19,78 & 3,15 \\
\hline \multirow{6}{*}{$\begin{array}{c}\text { TOTAL } \\
\text { ACCURACY }\end{array}$} & $4: 0$ & Control & 31,80 & 5,85 \\
\hline & & Study & 25,80 & 2,77 \\
\hline & $5: 0$ & Control & 47,33 & 1,78 \\
\hline & & Study & 34,00 & 8,81 \\
\hline & $6: 0$ & Control & 46,83 & 1,79 \\
\hline & & Study & 41,33 & 4,44 \\
\hline
\end{tabular}

The increase in lexical age of subgroups of five and six years was confirmed by their significantly better performance when compared to groups of four years of lexical age. This shows a relationship between the increase in receptive vocabulary and the refinement of phonological representations.

Taking into account the position of modification in nonwords, we found that modifications at initial and medial positions differentiate the subgroups of five and six years with children with SLI presenting a poorer performance. However, children of both groups (CG and SG) of lexical age of four did not differentiate. This shows that the main development occur after the lexical age of four years. When the modification occurred at final position, the groups did differ only at the lexical age of five.

Regarding the type of modification (addition or deletion), the same age effect was observed: the subgroups of five and six years of lexical age of the CG were better than the same subgroups of the SG.

These data are in agreement to other studies that have reported increased vocabulary with more clearly defined phonological representations. 2,7,14,15,16. 
TABLE 03. Mean and standard deviation values for each manipulation type according to lexical age

\begin{tabular}{|c|c|c|c|c|c|}
\hline MODIFICATION & $A G E$ & GROUP & MEAN & $\begin{array}{l}\text { STANDARD } \\
\text { DEVIATION }\end{array}$ & $p$ \\
\hline \multirow{6}{*}{ Mild } & \multirow[t]{2}{*}{$4: 0$} & Control & 6,30 & 3,13 & \multirow{2}{*}{0,655} \\
\hline & & Study & 5,60 & 1,82 & \\
\hline & \multirow[t]{2}{*}{$5: 0$} & Control & 11,68 & 0,89 & \multirow{2}{*}{$<0,001$} \\
\hline & & Study & 7,00 & 3,58 & \\
\hline & \multirow[t]{2}{*}{$6: 0$} & Control & 11,50 & 0,99 & \multirow{2}{*}{0,001} \\
\hline & & Study & 9,56 & 1,24 & \\
\hline \multirow{6}{*}{ Important } & \multirow[t]{2}{*}{$4: 0$} & Control & 5,90 & 3,38 & \multirow{2}{*}{0,225} \\
\hline & & Study & 3,80 & 1,92 & \\
\hline & \multirow[t]{2}{*}{$5: 0$} & Control & 11,83 & 0,39 & \multirow{2}{*}{0,001} \\
\hline & & Study & 6,83 & 4,40 & \\
\hline & \multirow[t]{2}{*}{$6: 0$} & Control & 11,83 & 0,51 & \multirow{2}{*}{0,009} \\
\hline & & Study & 10,11 & 2,52 & \\
\hline \multirow{6}{*}{ Addition } & \multirow[t]{2}{*}{$4: 0$} & Control & 2,70 & 1,83 & \multirow{2}{*}{0,910} \\
\hline & & Study & 2,80 & 0,84 & \\
\hline & \multirow[t]{2}{*}{$5: 0$} & Control & 5,75 & 0,87 & \multirow{2}{*}{0,001} \\
\hline & & Study & 3,00 & 2,00 & \\
\hline & \multirow[t]{2}{*}{$6: 0$} & Control & 5,67 & 0,77 & \multirow{2}{*}{0,006} \\
\hline & & Study & 4,56 & 1,13 & \\
\hline \multirow{6}{*}{ Deletion } & \multirow[t]{2}{*}{$4: 0$} & Control & 3,60 & 1,71 & \multirow{2}{*}{0,404} \\
\hline & & Study & 2,80 & 1,64 & \\
\hline & \multirow[t]{2}{*}{$5: 0$} & Control & 5,92 & 0,29 & \\
\hline & & Study & 4,00 & 1,79 & \\
\hline & $6: 0$ & Control & 5,83 & 0,38 & \\
\hline & & Study & 5,00 & 1,12 & \\
\hline & $4: 0$ & Control & 2,20 & 1,62 & 0016 \\
\hline & & Study & 0,80 & 0,84 & 0,010 \\
\hline Initiol & $5: 0$ & Control & 3,92 & 0,29 & \\
\hline 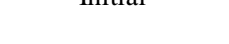 & & Study & 2,17 & 1,83 & 0,004 \\
\hline & $6: 0$ & Control & 4,00 & 0,00 & \\
\hline & & Study & 2,67 & 1,00 & \\
\hline & $4: 0$ & Control & 2,20 & 1,14 & 0757 \\
\hline & & Study & 2,40 & 1,14 & \\
\hline Modial & $5: 0$ & Control & 3,83 & 0,39 & 0018 \\
\hline 1VIecuiar & & Study & 2,00 & 1,26 & \\
\hline & $6: 0$ & Control & 3,94 & 0,24 & \\
\hline & & Study & 3,56 & 0,53 & דים \\
\hline & $4: 0$ & Control & 1,90 & 1,10 & 0263 \\
\hline & & Study & 2,40 & 0,55 & \\
\hline Cingl & $5: 0$ & Control & 3,92 & 0,29 & \\
\hline 1 IIIII & & Study & 2,83 & 1,17 & \\
\hline & $6: 0$ & Control & 3,56 & 0,78 & \\
\hline & & Study & 3,33 & 0,71 & (2) \\
\hline
\end{tabular}

$\mathbf{p}<\mathbf{0 , 0 5}$.
There are other factors that may contribute to the progressive refinement of phonological representations, such as the beginning of literacy. Children belonging to groups of five and six years of lexical age had already developed essential skills to the process of literacy such as activities involving metalinguistic representation, i.e. phonological awareness. 1,13

The feedback between the acoustic and articulatory representations and the early onset of babbling and vocal imitation also play an important role in the development and refinement of phonological representations. 17

Our results showed that children at four years of lexical age of the CG presented similar performance in a lexical decision task with nonwords both with mild and important manipulation. In contrast, children at four years of lexical age of the SG had more difficulties in the task involving nonwords with important manipulation. There was no difference in performance for children of lexical age of five and six years from both groups regarding the type of manipulation - mild or important. These results do not support a study in which major difficulty for children with SLI in the lexical decision with nonwords with mild modification was reported 2. The variables inherent to the different languages studied - French and Portuguese - may have influenced these results.

\section{Conclusion}

Thus, we can conclude that children with SLI have a deficit in phonological representation when compared to children with TLD. This difference in performance may be explained by differences in the construction and retention of representations in working memory, auditory discrimination, and motor planning and execution.

This study shows the importance of assessment and therapeutic approach in phonological representation and enables a better targeting of the therapeutic process. These representations are a crucial factor both for the development of phonological awareness and of oral language and writing. 


\section{References}

1. Sutherland D, Gillon GT. Assessment of phonological representations in children with speech impairment. Lang Speech Hear Ser. 2005;36:294-307.

2. Maillart C, Schelstraete MA, Hupet M. Phonological Representations in children with SLI: A study in French. J Speech Lang Hear R. 2004;47:187-98.

3. Edwards J, Lahey M. Non word repetition of children with specific language impairment: Exploration of some explanations for their inaccuracies. Appl Psycholinguist. 1998;19:279-09.

4. Gathercole S, Baddeley A. Phonological memory deficits in language disordered children: Is there a causal connection? J Mem Lang.1990;29:336-60.

5. Bridgeman E, Snowling M. The perception of phoneme sequence: a comparison of dyspraxic and normal children. Brit J Dis Comm. 1988;23(3):245-52.

6. Elbro C, Rasmussen I, Spelling B. Teaching reading to disabled readers with language disorders: a controlled evaluation of synthetic speech feedback. Scand J Psychol.1996;37(2):140-55.

7. Gray S. Word learning by preschoolers with specific language impairment: predictors and poor learners. J Speech Hear R. 2004;47(5):1117-32.

8. Metsala JL. An examination of word frequency and neighborhood density in the development of spoken-word recognition. Mem Cognition. 1997;25(1):47-56.

9. Dollaghan C, Campbell TF. Nonword repetition and child language impairment. J Speech Hear R. 1998; 41(5):113646.

10. Edwards J, Lahey M. Auditory lexical decision of children with specific language impairment. J Speech Hear R. 1996;39:1263-73.
11. Morselli AA, Befi-Lopes DM. Vocabulário Receptivo e Expressivo em crianças com desenvolvimento normal e com Distúrbio Específico de Linguagem [dissertação]. São Paulo (SP): Faculdade de Filosofia, Letras e Ciências Humanas da Universidade de São Paulo, São Paulo; 2003.

12. Befi-Lopes DM. Vocabulário. In: Andrade CRF de, BefiLopes DM, Fernandes FDM, Wertzner HF. ABFW - Teste de linguagem infantil: nas áreas de fonologia, vocabulário, fluência e pragmática. Barueri: Pró-Fono; 2004. cap2.

13. Sutherland D, Gillon GT. Development of phonological representations and phonological awareness in children with speech impairment. Int J Lang Comm Dis. 2007;42(2):22950 .

14. Jusczyk P. From general to language-specific capacities: The WRAPSA model of how speech perception develops. J Phonetics. 1993;21:3-28.

15. Kuhl PK. Infant speech perception: A window on psycholinguistic development. Int J Psycholinguistics. 1993;9:33-56.

16. Metsala JL, Walley AC. Spoken vocabulary growth and the segmental restructuring of lexical representations: Precursors to phonemic awareness and early reading ability. In Metsala JL, Ehri LC, editores. Word recognition in beginning literacy. Mahwah: NJ: Erlbaum; 1998. p. 89120

17. Plaut D, Kello C. The emergence of phonology from the interplay of speech comprehension and production: A distributed connectionist approach. In B. MacWhinney, editors. The emergence of language. Mahwah: NJ: Erlbaum; 1999. p. 381-415. 